\title{
Kernos
}

Revue internationale et pluridisciplinaire de religion grecque antique

19 | 2006

Varia

\section{Revue des actes de colloques et ouvrages collectifs}

\section{(2) OpenEdition \\ Journals}

Édition électronique

URL : https://journals.openedition.org/kernos/511

DOI : 10.4000/kernos.511

ISSN : 2034-7871

Éditeur

Centre international d'étude de la religion grecque antique

Édition imprimée

Date de publication : 1 janvier 2006

Pagination : 502-512

ISSN : 0776-3824

\section{Référence électronique}

"Revue des actes de colloques et ouvrages collectifs », Kernos [En ligne], 19 | 2006, mis en ligne le 22 mars 2011, consulté le 24 août 2022. URL : http://journals.openedition.org/kernos/511 ; DOI : https:// doi.org/10.4000/kernos.511

Tous droits réservés 
rationnelle, mais pas primitive pour autant, puisqu'elle est capable d'analyser la réalité à travers des instruments d'enquête et des valeurs sociales données.

Le dernier chapitre «Gli antichi e i loro indigitamenta » propose une étude des témoignages anciens sur la signification du mot indigitamenta. Les passages ne sont pas nombreux. Comme c'est souvent le cas dans ce genre d'études antiquaires, le point de départ est représenté par un passage de Servius, le commentateur de Virgile. Ce passage fait comprendre que les indigitamenta sont des listes de divinités : pas seulement les divinités mineures, mais toutes les divinités. Parmi les observations intéressantes de M.P., remarquons la suivante (p. 222) : pour beaucoup de divinités fonctionnelles la ratio équivaut à l'étymologie du nom divin. C'est pour cela que les Romains pouvaient évoquer sans difficultés les noms de leurs dieux en faisant des actions rituelles. La liste des indigitamenta est donc une liste des divinités, qui constitue un support à l'action rituelle et a pour but pratique de permettre à l'officiant d'évoquer la divinité qui convient dans chaque circonstance. Ensuite M.P. analyse la relation entre indigitamenta, incantamenta, carmina, indigitare, imprecari, etc. en mettant en relief que le premier mot comme les autres exprime un pouvoir d'influencer la réalité par la prononciation de paroles. M.P. affirme que les indigitamenta sont un «texte en vers à chanter, dans lequel sont annotées, pour ne pas se tromper, les paroles efficaces à adresser à chaque divinité, dont, avant tout, est enregistré le nom »(p. 240). Sur cette liste, les auteurs antiquaires ont construit leurs étiologies. M.P. se penche ensuite sur le verbe indigitare qui n'indique pas l'action générique de prier une divinité, mais qui est plutôt un terme technique indiquant le fait de l'invoquer avec le nom spécifique lié à une fonction et à un domaine précis. Enfin, M.P. analyse la relation entre indigitare et indiges. L'adjectif indiges pourrait indiquer une divinité qui a été rajoutée dans ces listes des dieux qui sont les indigitamenta. Le fait que ces listes étaient mises à jour par les pontifes est pertinent. M.P. remarque aussi, justement à mon avis, que quand les auteurs anciens rapportent quelques informations sur ces listes, ils le font parce que des innovations ont été apportées.

Les pages 264-265 résument les conclusions de ce travail. Mais un lecteur paresseux qui lirait les conclusions avant d'acheter le livre serait peut-être découragé. En fait, il est impossible de rendre compte, en si peu de place, d'un travail qui plonge dans les mécanismes fondamentaux de la théologie des Romains. Je conseille donc au lecteur de bien vouloir commencer par le début et de suivre attentivement l'ensemble des parcours auquel M.P. nous convie. Parmi ces lecteurs, ceux qu'intéresse la religion grecque trouveront à coup sûr dans cette « réflexion romaine » des points de comparaison extrêmement féconds.

Francesca Prescendi (Université de Genève)

\section{Actes de colloques, ouvrages collectifs et mélanges}

Barringer Judith, Hurwit Jeffrey M. (éds), Periklean Athens and its legacy. Problems and Perspective, Austin, Texas UP, 2005.

J. NeILS, The girl in the pithos: Hesiod's elpis, p. 37-45; H.A. SHAPIrO, The judgement of Helen in Athenian art, p. 47-62; B. SISMONDO RIDGWAY, 'Periklean' cult image and their media, p. 111118; E.B. HARRISON, Athena at Pallene and in the agora of Athens, p. 119-131; J.M. HuRWIT, The Parthenon and the temple of Zeus at Olympia, p. 135-145; J.M. BARRINGER, Alkamenes' Procne and Itys in context, p. 163-176; O. PALAGIA, Interpretations of two Athenian friezes: the temple on the 
Ilissos and the temple of Athena Nike, p. 177-192; C.C. VERMEULE II, Alpheos to the Orontes: an unusual echo of the Pheidian Zeus at the Syrian port of Seleukeia Pieria, p. 195-200.

Basset Louis, Biville Frédérique (éds), Les jeux et les ruses de l'ambiguité volontaire dans les textes grecs et latins. Actes de la Table ronde organisée à la Faculté des Lettres de l'univ. Lumière-Lyon 2 (23-24 nov. 2000), Lyon, Maison de l'Orient et de la Méditerranée - Jean Pouilloux, 2005 (Collection de la Maison de l'Orient et de la Méditerranée, 33. Série Linguistique et philologie, 4)

G. LuCAS, La réponse d'Ammon à Alexandre corrigée par Plutarque, p. 189-205; A. ORLANDINI, Paradoxes sémantiques, tautologies et textes oraculaires, p. 207-218; G. ROUGEMONT, Les oracles grecs recouraient-ils habituellement à l'ambiguïté volontaire?, p. 219-235.

Belayche Nicole, Brulé Pierre, Freyburger Gérard, Lehmann Yves, Pernot Laurent, Prost Francis (éds), Nommer les Dieux. Théonymes, épithètes, épiclèses dans l'Antiquité, Rennes/Turnhout, Presses Universitaires de Rennes/Brepols, 2005. (Recherches sur les rhétoriques religieuses, 5).

Pierre Brulé, Comment dire le divin? Introduction, p. 5-11; Nicole BeLAYCHE, Francis PROST, $1^{\text {re }}$ partie : Penser et écrire le nom. Introduction, p. 17-19; Marisa SQuILLANTE, La nominatio nella tradizione retorica e nella manualistica della tarda latinità, p. 21-40; Monique HaLm-Tisserant, Nommer les dieux au flanc des vases, p. 41-55; Ugo CRISCUOLO, Proclus et les noms des dieux: à propos du Commentaire au Cratyle, p. 57-68; Georg PETZL, Sur des noms de dieux dans l'épigraphie de l'Asie Mineure: différents degrés d'abstraction, p. 69-77; Christian Boudignon, Jésus et noms de scène du dieu des chrétiens, p. 79-92; John SCHEID et Jesper svEnBro, Les Götternamen de Hermann Usener: une grande théogonie, p. 93-103; Gérard FREYBURGER, G. Radke et le concept de la nomination divine, p. 105-110; Nicole BeLAYCHE, Francis Prost, 2 partie: Une théologie par le nom. Introduction, p. 113-114: Johann GOEKEN, Le nom de Zeus, p. 115-119; Paola CASSELla D'AMORE, La denominazione di Zeus 'TuÉoloৎ con particolare riferimento alla tragedia, p. 121-127; Gabriella PIRONTI, Au nom d'Aphrodite: réflexions sur la figure et le nom de la déesse née de l'aphros, p. 129-142; Pierre BRuLÉ, Le polythéisme en transformation: les listes de dieux dans les serments internationaux en Grèce antique ( $V^{e}$ - II siècle av. J.-C.), p. 143-173; Yves LeHMAnn, Théonymie et théologie chez les poètes latins archaïques, p. 175-181; Mariacarolina SANTORO, Ricerche sulle denominazioni divine nei papiri ercolanesi: l'opera teologica di Demetrio Lacone (PHerc. 1055), p. 183-199; Simon C. MimOUNI, Comment les chrétiens d'origine juive au í siècle ont-ils désigné leur messie Jésus?, p. 201-208; Nicole Belayche, Francis Prost, $3^{e}$ partie: La construction du nom et les fonctions des épiclèses. Introduction, p. 211-212; Paolo SCARPI, Des Grands dieux aux dieux sans nom: autour de l'altérité des dieux de Samothrace, p. 213-218; Robert PARKER, Artémis Ilithye et autres: le problème du nom divin utilisé comme épiclèse, p. 219-226; Jean-Baptiste CAYLA, Apollon ou la vie sauvage: à propos de quelques épiclèses d'Apollon à Chypre, p. 227-240; Anne JACQUEMIN, Panthéons et épiclèses delphiques: Apollon et les autres dieux, p. 241-253; Anne-Laure PHILIPpe,

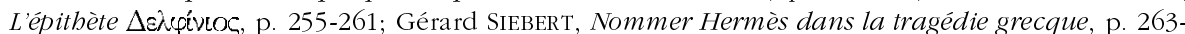
269; Vinciane Pirenne-Delforge, Des épiclèses exclusives dans la Grèce polythéiste? L'exemple d'Ourania, p. 271-290; Fabrice POLI, Jupiter Versor et Hercule Trinnianus : les épiclèses dans le monde oscophone, p. 291-304; Jean-Louis GIRARD, Mulciber: une épiclèses usuelle de Vulcain, p. 305-308; Françoise Labrique, Le Ba-Uni de Khonsou-Thot, juge et partie, p. 309-319; Nicole Belayche, Francis Prost, $4^{\circ}$ partie: Les noms des dieux à l'épreuve de l'histoire. Introduction, p. 323-324; Françoise ROUGEMONT, Les noms des dieux dans les tablettes inscrites en linéaire $B$, p. 325-388; Madeleine JosT, Quelques épiclèses divines en Arcadie: typologie et cas particuliers, p. 389-400; Charles-Marie TERNES, Les théonymes d'époque romaine en Rhénanie : ébauche d'une classification, p. 401-411; José D'ENCARNAÇAO, Les noms des dieux dans l'Hispania pré-romaine, p. 413-422; Marc Philonenko, Nommer le dieu Iaô, p. 423-426; Nicole Belayche, De la polysémie des épiclèses: "Yuı $\mathrm{T} \tau c c$ dans le monde gréco-romain, p. 427-442; Laurent BRICAULT, Toponymie

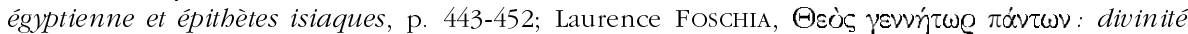


païenne et/ou chrétienne?, p. 453-466; Nicole Belayche, Francis Prost, 5 partie: Les noms des dieux dans l'adresse rituelle. Introduction, p. 469-471; Danièle Aubriot, L'invocation au $(x)$ $\operatorname{dieu}(x)$ dans la prière grecque: contrainte, persuasion ou théologie?, p. 473-490; Charles GUITTARD, Invocation et présence divine dans la prière à Rome, p. 491-501; Bernard LAUROT, Poséidon chez Pindare, Bacchylide et Eschyle, p. 503-511; Nadège Neumuller, Les épithètes cultuelles dans la Médée de Sénèque, p. 513-516; Martina ATZORI, La prière d'Admète dans l'Alceste de Barcelone: épiclèses et images traditionnelles, p. 517-526; Nicole BELAYCHE, Francis Prost, 6 partie: Des dieux et des hommes. Introduction, p. 529-530; Athanassia ZOGRAPHOU, Les Phôsphoroi et la tholos d'Athènes, p. 531-542; Antje KOLDE, Les épiclèses d'Asclépios dans l'inscription d'Isyllos d'Épidaure: implications politiques, p. 543-555; Jean-Luc VIX, Les épiclèses d'Asclépios dans les discours XXX et XXXIII d'Aelius Aristide, p. 557-566; Maud PFAFF-REYDELLET, Le rôle de l'épiclèses Vltor dans les Fastes d'Ovide, p. 567-577; Luigi SPINA, Modi divini di nominare gli uomini, p. 579-584; Christophe BADEL, Nommer d'après les dieux: les cognomina théophores chez les sénateurs du Haut empire, p. 585-597; Gérad FReYBURGER et Sihem SAKOUHI, Bibliographie générale, p. 599-609; Laurent PERNOT, Foi, rite, langage, p. 611-613.

Beltrán Lloris Francisco (éd.), Antiqua Iuniora. En torno al Mediterráneo en la Antigüedad, Zaragoza, 2004

Pilar RIVERO GRACIA, La política romana de concesión de privilegios a los santuarios griegos durante la República: nuevas interpretaciones, 13-26; Barbara SAVO, Le Cicladi in età romana. Siro: annotazioni storiche e religiose, p. 27-38.

Bertrand Jean-Marie (éd.), La violence dans les mondes grec et romain. Actes du colloque international (Paris, 2-4 mai 2004), Paris, Publications de la Sorbonne, 2005 (Histoire ancienne et médiévale - Université Paris I Panthéon-Sorbonne, 80).

Valérie HUET, La mise à mort sacrificielle sur les reliefs romains: une image banalisée et ritualisée de la violence?, p. 91-120; Anne JACQUEMIN, Images de violence et offrandes de victoire en Grèce ancienne, p. 121-136; Emma J. STAFFORD, Nemesis, Hybris and violence, p. 195-212; Marie-Christine Villanueva, Des ménades et de la violence dans la céramique attique, p. 225-246; Claudine LEDUC, La figure du père sacrificateur de sa fille dans les rituels athéniens, p. 271-286; Pierre Ellinger, Zeus et les limites de la répression, p. 349-364; Evelyne SCHEID, Remarques sur les fondements de la vengeance en Grèce archaïque et classique, p. 395-412; Sheila AGER, Sacred settlements: the role of the gods in the resolution of interstate disputes, p. 413-430.

Bodiou Lydie, Frère Dominique, Mehl Véronique (éds), L'expression des corps. Gestes, attitudes, regards dans l'iconographie antique, Presses Universitaires de Rennes, 2006. (Coll. Histoire. Cabiers d'histoire du corps antique, 2).

Francis Prost, Gestes des hommes, gestes des dieux. La représentation des gestes dans la plastique grecque archaïque et classique, p. 25-47; Sonia DARTHOU, Nina STRAWCZYNSKI, Naissance, reconnaissance, légitimation: les gestes de la filiation dans la céramique attique, p. 49-59; Geneviève HofFMANN, Ordre et variété dans la gestuelle des monuments funéraires attiques de l'époque classique, p. 61-74; Annie VERBANCK-PIÉRARD, La rencontre d'Héraclès et d'Athéna ou le regard des dieux, p. 133-151; Marie-Hélène Delavaud-Roux, Communiquer avec Dionysos: la danse des Ménades à travers l'iconographie des vases grecs, p. 153-163; Hélène BECTARTE, "Tenir un miroir» dans l'art funéraire antique, p. 165-180; Gaëlle FicHEuX, La chevelure d'Aphrodite et la magie amoureuse, p. 181-194; Dominique FRÈrE, Gestes quotidiens pour un parfum d'immortalité, p. 195-212; Christophe VENDRIEs, Orphée charmant les animaux. Attitudes et gestuelle du musicien et de son bestiaire dans la mosaïque romaine d'époque impériale, p. 233252; Marta PEDRINA, Tendre les mains, toucher du regard: Télèphe et Dryas, p. 299-310; Lydie BODIOU, De la mère à la fille: fusion, séparation, réconciliation. L'exemple de Déméter et Koré, p. 311-327; Philippe Monbrun, Les gestes de l'archer et du cithariste: des "corps à corps » apolliniens où l'esprit prend le relais, p. 329-346; Véronique MEHL, Caresser, conduire, contraindre. Les gestes entre les hommes et les animaux dans l'iconographie sacrificielle, p. 347-359. 
Bradshaw Aitken Ellen, Berenson MacLean Jennifer K. (éds), Philostratus' Heroikos. Religion and cultural identity in the third century C.E., Atlanta, Society of Biblical literature, 2004 (Writings from the Graeco-Roman World, 6).

C.O. PACHE, Singing heroes - the poetics of hero-cult in the Heroikos, p. 3-24; H.D. BETZ, Hero worship and Christian beliefs: observations from the bistory of religion on Philostratus's Heroikos, p. 25-47; C. DUÉ, G. NAGY, Illuminating the classics with the heroes of Philostratus, p. 49-73; Ch. JONES, Apollonius of Tyana, hero and holy man, p. 75-84; A. BLOMART, Transferring the cults of heroes in ancient Greece: a political and religious act, p. 85-98; W. BURKERT, Jason, Hypsipyle, and new fire at Lemnos: a study in myth and ritual, p. 99-123; F. MESTRE, Refuting Homer in the Heroikos of Philostratus, p. 127-141; J. RuSTEN, Living in the past: allusive narratives and elusive authorities in the world of the Heroikos, p. 143-158; S.E. ALCOCK, Material witness: an archaeological context for the Heroikos, p. 159-168; J.P. Hershbell, Philostratus' Heroikos and early Christianity: heroes, saints, and martyrs, p. 169-179; J.C. SKEDROS, The Heroikos and popular Christianity in the third century C.E., p. 181-193; J.K. BERENSON MACLEAN, Jesus and cult-hero in the fourth gospel, p. 195-218.

Brandt Barbara, Gassner Verena, LAdSTÄTter Sabine (éds), Synergia. Festschrift für Friedrich Krinzinger I-II, Wien, Phoibos, 2005.

Band II. H.S. Alanyali, Apollon Sidetes, p. 89-92; B. ОTTO, Olympische und chthonische Gottheiten, p. 329-338; U. Sinn, Olympias 'Neue Kleider'. Auf der Suche nach dem Kultbild des Zeusheiligtums, p. 361-365.

Cabanes Pierre, Lamboley Jean-Luc (éds), L'Tllyrie méridionale et l'Épire dans l'antiquité - IV. Actes du IV colloque intern. de Grenoble (10-12 octobre 2002), Paris, de Boccard, 2004 .

Ch. TzOuvara-SOuli, The cult of Zeus in ancient Epirus, p. 515-547; I. ANDRÉOU, Le sanctuaire de Dourouti: le culte et les pratiques religieuses dans le cadre matériel, p. 569-581; F. DRINI, Divinités et cultes dans les contrées antiques de l'actuelle Albanie à travers les inscriptions, p. 583587; V. BerETI, Aphrodite à Amantia, p. 589-594; F. QuANTIn, Artémis à Apollonia aux époques bellénistique et romaine, p. 595-608; A. Muller, F. TARTARI, I. TOÇI, Les terres cuites votives du 'sanctuaire d'Aphrodite' à Dyrrhachion. Artisanat et piété populaire, p. 609-622.

DEs Bouvrie Synnøve (éd.), Myth and Symbol II. Symbolic phenomena in ancient Greek culture. Papers from the second and third international symposia on symbolism at the Norwegian Institute at Athens, September 21-24, 2000 and September 19-22, 2002 Bergen, 2004 (Papers from the Norwegian Institute at Athens, 7).

Synnøve DES BOUVRIE, Introduction, p. 7-12; William HANSEN, Cognition and affect in oral narration, p. 13-24; Marjatta NIELSEN, The three ages of man. Myth and symbol between Chiusi and Athens, p. 25-41; Christoph AUFFARTH, Let women speak in the Assembly. Symbolic reversals in Aristophanes' Ekklesiazousai, p. 43-62; Pierre Ellinger, La fin des maux. Un nom-Pausanias - et un symbole (d'Homère à Pausanias le Périégète, en passant par Platon), p. 63-80; John HENDERson, Myth embedded in culture. The murals of Thorvaldsen's Museum, Copenhagen, p. 81-110; William HANSEN, Reading embedded narratives, p. 111-121; Jan BREMMER, Performing myths. Women's homes and men's leschai, p. 123-140; Christiane SOURVINOU-INWOOD, Reading a myth, reconstructing its constructions, p. 141-179; Pierre VIDAL-NAQUET, De l'Atlantide à Masada. Réflexions sur querelle, mythe, histoire et politique, p. 181-198; Minna SKAFTJE JENSEN, Myth and poetry in Archaic Greece. A comparative approach, p. 199-219; Virgilio MASCIADRI, Hypsipyle et ses sœeurs. Notes d'analyse structurale et historique, p. 221-241; David JORDAN, Two descriptions of myêsis, p. 243-278; Helène WHITTAKER, Board games and funeral symbolism in Greek and Roman contexts, p. 279-302; Jutta STROSZECK, Greek trophy monuments, p. 303-331; Louise BRUIT ZAIDMAN, Mythe et symbole religieux dans l'Hippolyte d'Euripide. Hippolyte entre Artémis et Aphrodite, p. 333-351; Synnøve DES BOUVRIE, Olympia and the epinikion. A creation of symbols, p. 353-391. 
Costas Rodríguez Jenaro (éd.), Ad amicam amicissime scripta. Homenaje a la profesora María José López de Ayala y Genovés, Madrid, 2005, 2 vols.

Alberto BERNABÉ, Un bimno tardio sobre la creación: tradición y novedad, I, p. 41-50; Helena Guzmán, Helena la maga (Odisea IV, 219-233), p. 69-76; Helena Rodriguez SOMOLINos, Safo, Titono y la cigarra (Pköln.inv.21351re + 21376 + POxy.1787), p. 129-138.

Destrée Pierre, Smith Nicolas D. (éds), Socrates’ Divine Sign: Religion, Practice, and Value in Socratic Philosophy, Kelowna B.C., Academic printing and publishing, 2005 (Apeiron, 38, 2).

Luc BRISSON, Socrates and the divine signal according to Plato's testimony: Philosophical practice as rooted in religious tradition, p. 1-12; Mark L. MCPHERRAN, Introducing new god: Socrates and his Daimonion, p. 13-30; Gerd VAN RIEL, Socrates' Daemon: Internalisatation of the divine and knowledge of the self, p. 31-42; Thomas C. BRICKHOUSE, Nicholas D. SMITH, Socrates' Daimonion and rationality, p. 43-62; Pierre DESTRÉE, The Daimonion and the philosophical mission: Should the divine sign remain unique to Socrates?, p. 63-79; Roslyn WEIss, For whom the Daimonion tolls, p. 81-96; Mark JOYAL, To Daimonion and the Socratic problem, p. 97-112; Michel NARCY, Socrates sentenced by his Daimôn, p. 113-125; Louis-André DORION, The Daimonion and the Megalêgoria of Socrates in Xenophon's Apology, p. 127-142; Aldo BRANCACCI, The double Daimôn in Euclides the Socratic, p. 143-154.

Elsner Jaś, Rutherford Ian, Pilgrimage in Graeco-Roman E Early Christian Antiquity, Oxford, University Press, 2005.

Jaś ELSNER, Ian RuTHERFORD, Introduction, p. 1-38; Barbara Kowalzig, Mapping out Communitas: Performances of Theoria in their sacred and political context, p. 41-72; Fred NAIDEN, Hiketai and Theoroi at Epidauros, p. 73-95; Michael ARNush, Pilgrimage to the Oracle of Apollo at Delphi: Patterns of Public and Private Consultation, p. 97-110; Scott SCULuON, 'Pilgrimage' and Greek religion: Sacred and secular in the pagan polis, p. 111-130; Ian RUTHERFORD, Down-stream to the Cat-goddess: Herodotus on Egyptian pilgrimage, p. 131-149; Andrea Wilson NigHTINGALE, The philosopher at the festival: Plato's transformation of traditional Theoria, p. 151-180; Alexia PETSALIS-DIOMIDIS, The body in the space: Visual dynamics in Graeco-Roman healing pilgrimage, p. 183-218; George WiLliamson, Mucianus and a touch of the miraculous: Pilgrimage and tourism in Roman Asia Minor, p. 219-252; William HuTTON, The construction of religious space in Pausanias, p. 291-317; Andrew FEAR, A journey to the end of the world, p. 319-331; Jane L. LIGHTFOOT, Pilgrims and ethnographers: In search of the Syrian goddess, p. 333-352; Savolta A. TAKÁCS, Divine and buman feet: records of pilgrims honouring Isis, p. 353-369; David NoY, Rabbi Aqiba comes to Rome: A Jewish pilgrimage in reverse?, p. 373-385; Wendy Pullan, 'Intermingled until the end of time': Ambiguity as a central condition for early Christian pilgrimage, p. 387-409; Jaś ElSNER, Piety and passion: contest and consensus in the audiences for early Christian pilgrimage, p. 411-434; David FRANKFURTER, Urban shrine and rural saint in fifth-century Alexandria, p. 435-449.

Georgoudi Stella, Koch Pietrre Renée, Schmidt Francis (sous la direction de), La cuisine et l'autel. Les sacrifices en questions dans les sociétés de la Méditerranée ancienne, Turnhout, Brepols, 2005 (Bibliothèque de l'École des Hautes Études - Sciences religieuses, 124).

Présentation, par St. GEORGOUd, R. KOCH PIETTRE, Fr. SCHMIDT, p. v-xvii; Alfred MARX, Tuer, donner, manger dans le culte sacrificiel de l'ancien Israël, p. 3-29; Louise BRUIT ZAIDMAN, Offrandes et nourritures: repas des dieux et repas des bommes en Grèce ancienne, p. 31-46; Catherine Graindorge, Le taureau blanc du dieu Min et l'offrande de la gerbe de blé, p. 47-76; Renée KOCH PIETTRE, Précipitations sacrificielles en Grèce ancienne, p. 77-100; Christophe BATSCH, Le Hêrem de guerre dans le judaïsme du deuxième temple, p. 101-111; Stella GEORGOUDI, L'" occultation de la violence» dans le sacrifice grec: données anciennes, discours modernes, p. 115-147; Catherine BOUANICH, Mise à mort rituelle de l'animal, offrande carnée dans le temple 
égyptien, p. 149-162; Françoise LABRIQUE, Le bras de Sekhmet, p. 163-176; Francis SCHMIDT, L'espace sacrificiel dans le judaïsme du Second Temple, p. 177-196; Athanassia ZOGRAFOU, Élimination rituelle et sacrifice en Grèce ancienne, p. 197-213; Jesper SvENBRO, La thusia et le partage. Remarques sur la « destruction » par le feu dans le sacrifice grec, p. 217-225; Jörg RüPKE, Gäste der Götter - Götter als Gäste: Zur Konstruktion des römischen Opferbanketts, p. 227-239; Guy BerTHIAUME, L'aile ou les mêria. Sur la nourriture carnée des dieux grecs, p. 241-251; Ulrike EgElHAAF-GAISER, Sakrallandschaften und Tafelluxus: Adaptation und Naturinszenierung in Banketträumen pompejanischer Kultgemeinschaften, p. 253-272; John SCHEID, Manger avec les dieux. Partage sacrificiel et commensalité dans la Rome antique, p. 273-287; Mareile HAASE, Etruskische Tieropferdarstellungen : Bild und Handlung, p. 291-307; Gilles D ORIVAL, L'originalité de la Bible grecque des Septante en matière de sacrifice, p. 309-315; Laurent PERNOT, Le sacrifice dans la littérature grecque de l'époque impériale, p. 317-328; Stéphane Toulouse, La Théosophie de Porphyre et sa conception du sacrifice intérieur, p. 329-341; Nicole BELAYCHE, Realia versus leges? Les sacrifices de la religion d'État au IV siècle, p. 343-370; Joan R. BRANHAM, Women as Objects of Sacrifice? An Early Christian 'Chancel of the Virgins', p. 371-386; Cristiano GROTTANELLI, Tuer des animaux pour la fête de Saint Félix, p. 387-407.

Greco Emanuele (éd.), Teseo e Romolo. Le origini di Atene e Roma a confronto. Atti del convegno intern. di studi. Scuola archeologica italiana di Atene, Atene, 30 giugno - 1 luglio 2003, Atene, Scuola archeologica italiana di Atene, 2005 (Tripodes, 1).

Emanuele GRECO, Introduzione, p. 9-12; Andrea CARANDINI, La nascita di Roma: Palatino, santuario di Vesta e foro, p. 13-28; Filippo COARELLI, I percorsi cerimoniali a Roma in età regia, p. 29-42; Noel RoBERTSOn, Athenian shrines of Aphrodite and the early development of the city, p. 43-112; Carmine AMPOLO, Hestia/Vesta tra mondo greco e Roma (I), p. 113-124; Pierre CARLIER, Les rois d'Athènes. Étude sur la tradition, p. 125-141; Jean-Marc LucE, Érechtée, Thésée, les tyrannoctones et les espaces publics athéniens, p. 143-164; Nicola F. PARISE, Plutarco e la tipologia

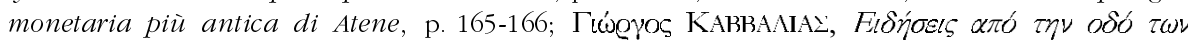
10ı Lo spazio pubblico e la formazione della città antica, p. 211-238; John SCHEID, Conclusions, p. $239-244$

von Haehling Raban (éd.), Griechische Mythologie und frühes Christentum, Darmstadt, Wissenschaftliche Buchgesellschaft, 2005.

M. FUHRMANn †, Mythen, Fabeln, Legenden und Märchen in der antiken Tradition. Mit einer Einleitung: Das Märchen von Amor und Psyche im 'Goldenen Esel' des Apuleius, p. 1-20; J.N. BREMMER, Myth and ritual in ancient Greece: observations on a difficult relationship, p. 21-43; K. BRODERSEN, 'Das aber ist eine Lüge!'- Zur rationalistischen Mythenkritik des Palaiphatos, p. 4457; K. Rosen, Der Mythos von Amor und Psyche in Apuleius' Metemorphosen, p. 58-64; W. SPEYER, Prophyrios als religiöse Persönlichkeit und als religiöser Denker, p. 65-84; R. ZIEGLER, Der PerseusMythos im Prestigedenken kaiserzeitlicher städtischer Eliten Kilikiens, p. 85-105; J. DRESKENWEILAND, Pagane Mythen auf Sarkophagen des dritten nachchristlichen Jabrbunderts, p. 106-131; F. SIEGERT, Griechische Mythen im hellenistischen Judentum, p. 132-152; D. DORMEYER, Bakchos in der Apostelgeschichte, p. 153-172; W. BURKERT, Kritiken, Rettungen und unterschwellige Lebendigkeit griechischer Mythen zur Zeit des frühen Christentums, p. 173-193; Ch. GNILKA, Wabrheit und Ähnlichkeit, p. 194-226; Ch. MARKSCHIES, Odysseus und Orpheus - christliche gelesen, p. 227-253; W. GEERLINGS, Orpheus in der vorkonstantinischen griechischen Theologie, p. 254-267; H. SCHOlTEN, Der Demeter- und Persephonemythos in der Auseinandersetzung christlicher Autoren, p. 268-294; St. VANDERHEIJDEN, Mythos zwischen Aberglaube und Philosophie in den Stromateis des Clemens von Alexandrien, p. 295-310; B. OEHL, Mythos und Häresie, p. 311-338; R. VON HAEHLING, Voraussebung und Willensfreibeit: Die geistige Auseinandersetzung der früben Christen mit dem Erzählgut der griechischen Tragödie, p. 339-358; J. RüPKE, Bilderwelten und Religionswechsel, p. 359-376. 
Hägg Robin, Alroth Brita (éds), Greek Sacrificial Ritual, Olympian and Chthonian. Proceedings of the Sixth International Seminar on Ancient Greek Cult, organized by the Department of Classical Archaeology and Ancient History, Göteborg University, 25-27 April 1997, Stockholm, Åströms Förlag, 2005 (Acta Instituti Atheniensis Regni Sueciae, Series in- $\left.8^{\circ}, 18\right)$.

B.C. DIETRICH $\dagger$, Some thoughts on sacrificial ritual and meaning (abstract), p. 9-10; Christoph AUfFARTH, How to sacrifice correctly-without a manual, p. 11-21; Scott SCuLlion, Saviours of the father's hearth': Olympian and chthonian in the Oresteia, p. 23-36; Robert PARKER, ic ñow!

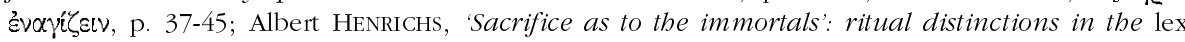
sacra from Selinous and other inscriptions, p. 47-60; Birgitta BERGQUIST $t$, A re-study of two

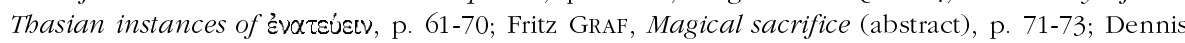
D. Hughes, Sacrifice and the cult of the dead in ancient Argos, p. 75-83; Noel ROBERTSON, Sacrifice to the sea: a custom prior to the 'Olympian' and 'chthonian' categories?, p. 85-98; Carla M. ANTONACCIO, Dedications and the character of cult, p. 99-112; Charlotte WIKANDER, The practicalities of ruler cult, p. 113-120; David S. REESE, Faunal remains from Greek sanctuaries: a survey (abstract), p. 121-123; Elizabeth R. GEBHARD, David S. REESE, Sacrifices for Poseidon and Melikertes at Isthmia, p. 125-154; Jan N. BREMMER, The sacrifice of pregnant animals, p. 155-165; Kevin CunTon, Pigs in Greek rituals, p. 167-179; Claude CALAME, Heracles, animal and sacrificial victim in Sophocles' Trachiniae?, p. 181-195; Folkert VAN STRATEN, The priest's role in Greek sacrifice: iconographical considerations (abstract), p. 197-199; Nanno MARINATOS, Symbolic forms of sacrificial imagery in the Eastern Mediterranean, p. 201-208.

Hernández Guerra Liborio, Alvar EzQuerra Jaime (éds.), Jerarquías religiosas y control social en el mundo antiguo. Actas del XXVII Congreso Internacional GIREA-ARYS. Valladolid, 7-9 de noviembre, 2002, Valladolid, Universidad, 2004.

Adolfo J. DOMinguez MONEDERO, Los sacerdocios hereditarios en Grecia, ¿control social o promoción personal?, p. 151-161; Domingo PLACIDO, Las prácticas religiosas atenienses y el control social de la democracia, p. 163- 167; Miriam VALdÉs GuíA, Los Cérices en Atenas arcaica y los misterios de Agra: korynephoroi de Pisistrato e iniciación eleusina, p. 169-184; Vasilis TsIOLIS, Religiosidad y control social en Arcadia, p. 185-192; Richard GORDON, Social Control in the Lydian and Phrygian 'Confession' Texts, p. 193-203; Ana IRIARTE, Soberaní, sacerdocio y pacifismo en el Oriente de Esquilo, p. 205-214; María Cruz CARDETE DEL OLMO, La construcción de un mito: el encuentro entre Pan y Filipides en el Partenio, p. 215-223; María Dolores MIRON PEREZ, Sacerdotisas griegas, prestigio social y orden de género: la sacerdotisa de Atenea Poliade y las dieciséis mujeres de Olimpia, p. 225-233; Carmen BARRIGON, La presencia de la sacerdotisa anciana en los santuarios griegos: una aproximación, p. 235-244; Juan José FERRER MAESTRO, Verónica MARSA GONZALEZ, Superstición, ambigüedad e intereses corporativos en torno al oráculo de Delfos, p. 245249; Colette JOURDAIN-ANNEQUIN, Religion et contrôle social : l'exemple du culte des Palikes, p. 261269; Arminda LOZANO VElilla, El poder sacerdotal en el ámbito minorasiático durante el imperio belenístico-romano, p. 271-284.

Hirsch-Luipold Rainer (éd.), Gott und die Götter bei Plutarch. Götterbilder - Gottesbilder-Weltbilder, Berlin, de Gruyter, 2005 (RGVV, 54)

R. HiRsCh-LuIPOLD, Einleitung, p. 1-10; F. FERRARI, Der Gott Plutarchs und der Gott Platons, p. 13-25; F.E. BRENK, Plutarch's middle-platonic gods: about to enter (or remake) the Academy, p. 27-49; J. OpsOMER, Demiurges in early imperial Platonism, p. 51-99; A. PÉREZ JIMÉNEZ, Aluxıooúun als Wesenszug des Göttliches, p. 101-109; F. FRAZIER, Göttlichkeit und Glaube. Persönliche Gottesbeziehung im Spätwerk Plutarchs, p. 111-137; R. HIRSCH-LuIPOLD, Der eine Gott bei Philon von Alexandrien und Plutarch, p. 141-168; H. GÖRGEMANNs, Eros als Gott in Plutarchs 'Amatorius', p. 169-195; P.A. STADTER, Plutarch and Apollo of Delphi, p. 197-214; R. FELDMEIER, Osiris. Der Gott der Toten als Gott des Lebens (De Iside Kap. 76-78), p. 215-227; L. VAN DER STOCKT, No cause of alarm: chthonic deities in Plutarch, p. 229-249; Fr. GRAF, Plutarch und die Götterbilder, p. 251-266. 
Hoffmann Adolf (éd.), Ägyptische Kulte und ihre Heiligtümer im Osten des römischen Reiches. Intern. Kolloquium 5./6. September 2003 in Bergama (Türkei), Istanbul, Ege Yayınlar1, 2005 (Veröffentlichungen des Deutschen Archäologischen Instituts Istanbul. Byzas, 1).

A. HofFmann, Die Rote Halle in Pergamon - Eine komplizierte Forschungsgeschichte mit Zukunftsperspektiven, p. 3-20; U. MANIA, Neue Ausgrabungen - neue Aspekte in der Erforschung der Roten Halle, p. 21-34; C. BRÜCKENER, Die Rote Halle aus baubistorischer Sicht - Neue Dokumentationsarbeiten, p. 35-46; K. LEMBKE, Kolossalität und Monumentalität: Zur Größe und Ausdebnung der Roten Halle, p. 47-57; W. RADT, Spuren Ägyptischer Kulte in Pergamon, p. 59-79; A.-K. RIEGER, Pergamon und Rom. Überlegungen zur städtebaulichen Bedeutung und zur Bauherrschaft der Roten Halle in Pergamon, p. 81-94; B.B.M. ÜNLÜOĞLU, The cult of Isis in Asia Minor, p. 95-108; P. SCHERRER, Das sogenannte Serapeion in Ephesos: ein Mouseion?, p. 109-138; A. HenNEMEYer, Das Heiligtum der Ägyptischen Götter in Priene, p. 139-153; S.A. TAKÁcs, Cult, dedicators, and dedications of Isis and Sarapis in Lydia and Mysia, p. 155-168; M. KREEB, Überlegungen zu einem Bronzeobjekt aus Kalymnos, p. 169-179; S. ENSOLI, L'Egitto, la Libia e la più antica diaspora del culto isiaco nel bacino del mediterraneo: il santuario di Iside e Serapide sull'Acropoli di Cirene, p. 181-196; M. HAASE, Zu einem Repertoire der Isis-Heiligtümer im kaiserzeitlichen Ägypten, p. 197-208; F. TIRADRITTI, The return of Isis in Egypt. Remarks on some statues of Isis and on the diffusion of her cult in the Graeco-Roman world, p. 209-225; M. BOMMAS, Das Isisbuch des Apuleius und die Rote Halle von Pergamon. Überlegungen zum Kultverlauf in den Heiligtümern für ägyptische Gottheiten und seinen Ursprüngen, p. 227-245; J. EINGARTNER, Heiligtümern für ägyptischer Gottheiten in Nordafrika: Aspekte religiöser und gesellschaftlicher Bedeutung, p. 247-258; U. EGELHAAF-GAISER, Exklusives Mysterium oder inszeniertes Wissen? Die ägyptischen Kulte in der Darstellung des Pausanias, p. 259-280.

Howgego Christopher, Heuchert Volker, Burnett Andrew (éds), Coinage and identity in the Roman provinces, Oxford, Univ. Press, 2005.

U. PETER, Religious-cultural identity in Thrace and Moesia Inferior, p. 107-114; S. PRICE, Local mythologies in the Greek East, p. 115-124; D.O.A. KLOSE, Festivals and games in the cities of the East during the Roman empire, p. 125-133.

HunTER Richard (éd.), The Hesiodic Catalogue of Women. Constructions and reconstructions, Cambridge, Univ. Press, 2005.

R. OsBorne, Ordering women in Hesiod's Catalogue, p. 5-24; J. STRAuss Clay, The beginning and end of the Catalogue of women and its relation to Hesiod, p. 25-34; E. IRWIN, Gods among men? The social and political dynamics of the Hesiodic Catalogue of women, p. 35-84; J. HAUBOLD, Heracles in the Hesiodic Catalogue of women, p. 85-98; I. RUTHERFORD, Mestra at Athens: Hesiod fr. 43 and the poetics of panbellenism, p. 99-117; E. CINGANO, A catalogue within a catalogue: Helen's suitors in the Hesiodic Catalogue of women (frr. 126-204), p. 118-152; R.P. MARTIN, Pulp epic: the Catalogue and the Shield, p. 153-175; G.B. D'AlEssio, The Megalai Ehoiai: a survey of the fragments, p. 176-216; id., Ordered from the Catalogue: Pindar, Bacchylides, and Hesiodic genealogical poetry, p. 217-238; R. HunTER, The Hesiodic Catalogue and Hellenistic poetry, p. 239265; H. AsQuiTH, From genealogy to Catalogue: the Hellenistic adaptation of the Hesiodic catalogue form, p. 266-286; Ph. HARDIE, The Hesiodic Catalogue of women and Latin poetry, p. 287-298; R. FLETCHER, Or such as Ovid's Metamorphoses, p. 299-319.

Johnston Sarah Iles, STRuck Peter T., Mantikê. Studies in Ancient Divination, Leiden, Brill, 2005 (Religions in the Graeco-Roman World, 155).

Sarah ILES JOHnSTON, Divining divination, p. 1-28; Walter BuRKERT, Signs, commands, and knowledge: Ancient divination between enigma and epiphany, p. 29-49; Fritz GRAF, Rolling the dice for an answer, p. 51-97; William E. KLINGSHIRN, Christian divination in late Roman Gaul: the sortes Sangallenses, p. 99-128; Cristiano GROTTANELLI, Sorte unica pro casibus pluribus enotata: Literary texts and lot inscriptions as sources for ancient kleromancy, p. 129-146; John DILLERY, 
Chresmologues and manteis: Independent diviners and the problem of authority, p. 167-231; David FRANKFURTER, Voices, books, and dreams: The diversification of divination media in late antique Egypt, p. 233-254; Christopher A. FARAONE, Necromancy goes underground: The disguise of skulland corpse-divination in the Paris magical papyri (PGM IV 1928-2144), p. 255-282; Sarah ILES Johnston, Delphi and the Dead, p. 283-306.

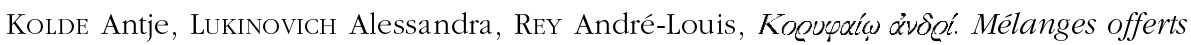
à André Hurst, Genève, Droz, 2005 (Recherches et Rencontres. Publications de la Faculté des lettres de Genève, 22).

Albert SCHACHTER, The Singing Contest of Kitharion and Helikon: Korinna, fr. 654 PMG col. $i$ and ii.1-11: Content and Context, p. 275-283; Paul SCHUBERT, Xénophon dans le rôle d'un second Ulysse ou les conséquences de l'impiété, p. 285-292; Martin STEINRÜCK, Le Catalogue des femmes pseudo-hésiodique et les rares amants héroïques des déesses, p. 293-302; Francis VIAN, Bacchantes nonniennes. Diversité et cohérence, p. 303-309; Philippe BORGEAUD, Bachofen, Apollonios de Rhodes et Huntington. Esquisse, p. 323-332; Philippe LusIER, $\Sigma u ̈ v ~ \theta \varepsilon \tilde{u}$. Signification et destin d'une formule d'invocation en Égypte, p. 339-346; Nadina RADEVA GIROD, Les Mystères d'Andania. Traduction de l'inscription $n^{\circ} 65$ de Lois sacrées des cités grecques, Sokolowski (1969), p. 357-365; Claire-Françoise DE Roguin, Les querelles d'Océanos et de Téthys : de l'Enûma Elish à la cosmogonie d'Empédocle, p. 377-384; Jean RuDHARDT, Quelques notes sur la religion, p. 385-398.

Mortier-Waldschmidt Odile, Musique \& Antiquité. Actes du colloque d'Amiens, 25-26 octobre 2004, Paris, Les Belles Lettres, 2006.

Danièle AuBriot, De la lyre à l'arc. Fonctions religieuses de la musique chez Homère, p. 1742; Claude CALAME, Jeux de genre et performance musicale dans le chour de la tragédie classique : espace dramatique, espace cultuel, espace civique, p. 62-90; Anne Gabrièle WERSINGER, Un élément musical inaperçu dans le Mythe d'Ér: l'bymne des Moires et l'heptacorde inversé, p. 146-164; Sylvie David-Guignard, Bâtir en musique : l'exemple d'Amphion à Thèbes, p. 247-266.

Mylonopoulos Joannis, Roeder Hubert (éds), Archäologie und Ritual. Auf der Suche nach der rituellen Handlung in den antiken Kulturen Ägyptens und Griechenlands, Wien, Phoibos Verlag, 2006.

Diamantis PANAGIOTOPOUlos, Das minoische Stierspringen. Zur Performanz und Darstellung eines altägäischen Rituals, p. 125-138; Anja KLÖCKNER, Votive als Gegenstände des Rituals - Votive als Bilder von Ritualen. Das Beispiel der griechischen Weibreliefs, p. 139-152; Katja SPORN, Das Göttliche im Menschenbild. Religiöse Elemente im griechischen Grabrelief, p. 153-166; Torsten MATTERN, Architektur und Ritual. Architektur als funktionaler Rabmen antiker Kultpraxis, p. 167183; Joannis Mylonopoulos, Das Heiligtum des Zeus in Dodona. Zwischen Orakel und venatio, p. 185-214; Helga BumKe, Die Schwester des Orakelgottes. Zum Artemiskult in Didyma, p. 215-237.

Olmos Ricardo, Cabrera Pilar, Montero Santiago (éds.), Paraíso cerrado, jardín abierto. El reino vegetal en el imaginario religioso del Mediterráneo, Madrid, 2005.

Ricardo Olmos, Imaginarios de la physis y del brotar en el antiguo Mediterráneo, p. 9-32; Carolina LOPEZ RuIZ, El dicho del árbol y la piedra. Sabiduría ancestral y árboles sagrados en Grecia arcaica y el Levante, p. 103-124; Margarita MORENO CONDE, Flor y ritos de infancia en la antigua Grecia: azafrán, narciso y jacinto, p. 125-146; Pilar CABRERA, El dios entre las flores. El mundo vegetal en la iconografía de la Magna Grecia, p. 147-170

Pedregal Rodríguez Amparo, González González Marta (éds.), Venus sin espejo. Imágenes de mujeres en la antigüedad clásica y el cristianismo primitivo, 2005

Manuel GARCia TeIJEIRO, De maga a bruja. Evolución de la hechicera en la Antigüedad clásica, p. 33-54; Marta GonZalez Gonzalez, Lo bello y lo siniestro. Imágenes de la Medusa en la antigüedad, p. 121-138. 
Ries Julien (éd.), avec la collaboration d'André MotTe et de Natale SpinETo, Les civilisations méditerranéennes et le sacré, Turnhout, Brepols, 2003 (Homo Religiosus. Série II, 4).

Bernard C. DIETRICH, Religion, culte et sacré dans la civilisation créto-mycénienne, p. 69-92; Ileana Chirassi COLOMBO, Le sacré dans l'espace politique [grec]: mythes d'origine, rites d'intégration, p. 207-228; André MOTTE, Le sacré dans la nature et dans l'homme: la perception du divin chez les Grecs, p. 229-254; Ugo Bianchi, Mystères d'Éleusis. Dionysisme. Orphisme, p. $255-282$.

SEgARRA CRESPO Diana (éd.), Transcurrir y recorrer. La categoría espacio-temporal en las religiones del mundo clásico. Actas del I Seminario bispano-italiano de historia de las religiones, Madrid, 2003

M. Rocchi, Dike sopra i monti, Parthenos tra gli astri (Arat., Phaen, 98-136), p. 45-63; A.M.G. CAPOMACCHIA, L'eroe passa: la definizione spazio-temporale della realtà attraverso gli itinerari eroici, p. 107-113.

Sfameni Gasparro Giulia (éd.), Modi di comunicazione tra il divino e l'umano. Tradizioni profetiche, divinazione, astrologia e magia nel mondo mediterraneo antico. Atti del II Seminario Internazionale Messina 21-22 Marzo 2003, Cosenza, Edizioni L. Giordano, 2005. 1 vol. $14 \times 20,5$ cm, 383 p. (Hierá. Collana di studi storico-religiosi, 7. Temi e problemi della Storia delle Religioni nell'Europa contempranea, 2).

Emilio SUÁREZ DE LA TORRE, Forme e funzioni del fenomeno profestico e divinatorio dalla Grecia classica al periodo tardo-antico, p. 29-106; Alberto BERNABÉ, La tradizione orfica dalla Grecia classica al Neoplatonismo, p. 107-150; Aurelio PÉREZ JIMÉNEZ, Prescrizioni astrologiche relative alla prassi religiosa, p. 151-190; Attilio MASTROCINQUE, Pregare Ialdabaoth (Il Dio seduto sul settimo cielo nelle preghiere magiche), p. 191-222; Giovanni FILORAMO, La falsità della profezia e la costruzione della communità cristiana, p. 223-246; Giulia SFAMENI GASPARRO, Il sofista e l'« uomo divino »: Filostrato e la costruzione della vera storia di Apollonio di Tiana, p. 247-310; Mariangela MONACA, Prodigi e profezie nel mondo romano: peculiarità della rivelazione sibillina, p. 311-346; Augusto Cosentino, Due maghi-illusionisti: Anassilao di Larisa e Marco il Mago, p. 347-354; Ennio SANZI, Magia e Culti orientali V. Che ci fa il dio Mithra in un papiro magicooracolare? Ovverosia note sotrico-religiose intorno a PGM V 1-53, p. 355-383.

Yatromanolakis Dimitrios, Roilos Panagiotis (éds), Greek Ritual Poetics, Washington, D.C., Center of Hellenic Studies, Trustees for Harvard University/Athens, Foundation of the Hellenic World, 2006.

Dimitrios YATROMANOLAKIS, Panagiotis ROILOS, Provisionally structured ideas on a beuristically defined concept: toward a ritual poetics, p. 3-34; Robin OSBORNE, Monumentality and ritual in Archaic Greece, p. 37-55; Dimitrios YATROMANOLAKIs, Ritual poetics in Archaic Lesbos: contextualizing genre in Sappho, p. 56-70; Richard SEAFORD, Tragedy, ritual, and money, p. 71-93; Margaret ALEXIOU, Not by words alone: ritual approaches to Greek literature, p. 94-120; Panayotis RoILOS, Ritual and poetics in Greek modernism, p. 121-136; Gregory NAGY, Poetics of repetition in Homer, p. 139-148; Pat EASTERLing, Now and forever in Greek drama and ritual, p. 149-160; Christiane SOURVINOU-INWOOD, Gendering the Athenian funeral: ritual reality and tragic manipulations, p. 161-188; Albert HENRICHS, 'Let the good prevail': perversions of the ritual process in Greek tragedy, p. 189-198; John DufFy, Playing at ritual: variations on a theme in Byzantine religious tales, p. 199-209; Panagiotis RoILOs, The sacred and the profane: re-enacting ritual in the Medieval Greek novel, p. 210-226; Vangelis CALOTYCHOS, Human rites: building and boming bridges in the Balkans, p. 227-242; Gloria FERRARI, The 'Anodos' of the bride, p. 245-260; Angus BOwIE, The narratological role of social and religious rituals in Herodotus' Histories, p. 261-278; Ioli KALAVREZOU, Dance as ritual, dance as performance, p. 279-296; Anna STAVRAKOPOULOU, Wedding: re-composing a ritual in shadow theater performances, p. 297-306; Gail HOLST-WARHARFT, 
The body's language: representations of dance in modern Greek literature, p. 307-320; Ian RUTHERFORD, In a virtual wild space: pilgrimage and rite de passage from Delphi to Sabarimalai, p. 323-337; Charles STEWART, Ritual dreams and historical orders: incubation between paganism and christianity, p. 338-355; Ruth MACRIDES, The ritual of petition, p. 356-370; Michael HERZFELD, Rites of spring: ritual, resistance, and taxonomic regimentation in Greek cultural history, p. 371382; Laurie KAIN HART, How to do things with things: architecture and ritual in Northern Greece, p. 383-404; Jane K. CowAN, Little soldiers for/against the state: embodied repositionings in a male rite of passage in Northern Greece, p. 405-424.

\section{Contributions particulières}

BARRIGON FuENTES María del Carmen, « El reto de la mujer griega. La presencia del sacerdocio en la Historia de las Mujeres », in María Jesús DuEÑAs, Magdalena Santo TOMÁs PÉREZ, Cristina DE LA Rosa Cubo, María Isabel DEL VAL (éds), La bistoria de las mujeres. Una revisión bistoriográfica, 2004, p. 121-138.

Bowden H., «Xenophon and the scientific study of religion », in Chr. Tuplin (éd.), Xenophon and his world. Papers from a conference held in Liverpool in July 1999, Stuttgart, Steiner, 2004 (Historia. Einzelschriften 172), p. 229-246.

BRENK Frederick E., «O sweet mystery of the Lives! The eschatological dimension of Plutarch's biographies ", in L. DE BloIs, J. BONS, T. Kessels, D.M. SCHENKEVELd (éds), The statesman in Plutarch's works. Proceedings of the Gth intern. conference of the International Plutarch Society, Nijmegen/Castle Hernen, May 1-5, 2002. II: The statesman in Plutarch's Greek and Roman Lives, Leiden, Brill, 2005 (Mnemosyne, suppl. 250, 2), p. 61-73.

BROwN Edwin L., " In search of Anatolian Apollo », in A.P. CHAPIN (éd.), Charis. Essays in honour of Sara A. Immerwahr, Athens, American School of Classical Studies, 2004 (Hesperia, suppl. 33), p. 243-257.

CHANIOTIS Angelos, "Ritual dynamics in the Eastern Mediterranean: Case studies in ancient Greece and Asia Minor », in W.V. HARRIS (éd.), Rethinking the Mediterannean, Oxford, Univ. Press, 2005 p. 141-166.

D'AGata A.L., «Cult activity on Crete and Cyprus at the end of the late Bronze age and the beginning of the early Iron age », in H. MATTHÄUs, S. ROGGE (éds), Cyprus: Religion and society from the late Bronze age to the end of the archaic period. Proceeding of an intern. symposium on Cypriote archaeology, Erlangen, 23-24 July 2004, Nicosia, Foundation A.G. Leventis, Univ. of Erlangen-Nürnberg, Institute for classical archaeology, Univ. of Münster, Institute for interdisciplinary Cypriot Studies, Möhnesee-Wamel, Bibliopolis, 2005, p. 1-17.

DickIE M.W., "The eschatology of the epitaphs in the new Posidippus papyrus », in F. CAIRNS (éd.), Greek and Roman poetry. Greek and Roman bistoriography. Papers of the Langford Latin seminar, ARCA. Classical and medieval texts, papers and monographs 44, 2005, p. 19-51.

FENET A., «Sanctuaires marins du canal d'Otrante », in E. DENIAux (éd.), Le canal d'Otrante et la Méditerranée antique et médiévale. Colloque organisé à l'Université de Paris X-Nanterre (2021 nov. 2000), Bari, Edipuglia, 2005 (Insulae Diomedeae, 2), p. 39-49.

FRISONE F., « Il rituale come campo di sperimentazione del 'politico': l'esempio della normativa sul rituale funerario nella documentazione epigrafica greca », in S. CATALDI (éd.), Poleis e politeiai. Esperienze politiche, tradizioni letterarie, progetti costituzionali. Atti del convegno intern. di storia greca, Torino, 29-31 maggio 2002, Alessandria, Ed. dell'Orso, 2004 (Fonti e studi di storia antica, 13), p. 369-384.

Herrero Ingelmo María Cruz, « Héroes epónimos en Pausanias », in S. CResPo, A. Alonso Ávila (éds.), Scripta antiqua in honorem Angel Montenegro Duque et José María Blázquez Martínez, Valladolid, 2002, p. 125-133.

Horstmannshoff H.F.J., " 'Did the god learn medicine?' Asclepius and temple medicine in Aelius Aristides' Sacred tales ", in H.F.J. HORSTMANSHOFF, M. STOL (éds), Magic and rationality in ancient Near Eastern and Graeco-Roman medicine, Leiden, Brill, 2004 (Studies in ancient medicine, 27), p. 325-341 
INTERDONATO E., «Evergetismo e dediche nei santuari greci in età romana: il caso dell'Asklepieion di Kos », in M. CÉBeillac-Gervasioni, L. LAmoine, Fr. Trément (éds), Auto-célébration des élites locales dans le monde romain. Contextes, images, textes (II s. av.J.-C. / III s. ap. J.-C.), Clermont-Ferrand, Presses univ. Blaise-Pascal, 2004 (Erga, 7), p. 267-285.

KÖHnKEn A., "Artemis in Artemishymnos des Kallimachos », in M.A. HARdER, R.F. RegTUiT, G.C. WAKKER (éds), Callimachus II, Leuven, Peeters, 2004, p. 161-171.

KOKKOROU-AlEvras G., "New epigraphical evidence on the cults of ancient Halasarna in Cos », in K. Höghammar (éd.), The Hellenistic polis of Kos. State, economy, and culture. Proceedings of an intern. seminar organized by the Department of archaeology and ancient history, Uppsala Univ., 11-13 May 2000, Uppsala, Univ. Library, 2004 (Boreas, 28), p. 119-127.

LApatin K., "The statue of Athena and other treasures in the Parthenon », in J. Neils (éd.), The Parthenon. From antiquity to the present, Cambridge, UP, 2005, p. 261-291.

MaRTín García José Antonio, "Héroes, dragones y princesas en el mito griego », in Juan Francisco MaRTos MONTIEL, Cristóbal Macías Villalobos (éds), Thamyris, Cuadernos de Cultura Clásica: Studia varia in memoriam Prof. Salvador Claros, Málaga, 2005, p. 13-20

Mastronarde D., «The gods », in J. Gregory (éd.), A Companion to Greek Tragedy, Oxford, Blackwell, 2005, p. 321-332.

NiETO IBÁÑEZ Jesús-María, « La mujer en el deporte griego: mitos y ritos femeninos », in JesúsMaría NiETO IBÁÑEZ (éd.), Estudios sobre la mujer en la cultura griega y latina. XVIII Jornadas de Filología Clásica de Castilla y León. León, 2-5 de noviembre de 2004, León, Universidad, 2005, p. 63-82.

PRENT M., " Cult activites at the palace of Knossos from the end of the Bronze age: continuity and change ", in G. CAdogan, E. Hatzaki, A. VAsilakis (éds), Knossos. Palace, city, state. Proceedings of the conference in Herakleion organized by the British school at Athens and the 23th Ephoreia of prebistoric and classical antiquities of Herakleion, in November 2002, for the centenary of Sir Arthur Evans' excavations at Knossos, London, The British School at Athens, 2004, p. 411-419.

QuANTin François, "Le dieu Pan au féminin à Bouthrôtos: une influence italienne? ", in E. Deniaux (éd.), Le canal d'Otrante et la Méditerranée antique et médiévale. Colloque organisé à l'Université de Paris X-Nanterre (20-21 nov. 2000), Bari, Edipuglia, 2005 (Insulae Diomedeae, 2), p. 67-79.

RAMELLI Ilaria «L'interpretazione allegorica filosofica di Zeus come Padre nello Stoicismo », in Marcos Ruiz SÁNCHEZ (éd.), Visiones mítico-religiosas del padre en la antigüedad clásica, Madrid, 2004, p. 155-180.

RIgSBy K.J., "Theoroi for the Koan Asklepieia », in K. Höghammar (éd.), The Hellenistic polis of Kos. State, economy, and culture. Proceedings of an intern. seminar organized by the Department of archaeology and ancient history, Uppsala Univ., 11-13 May 2000, Uppsala, Univ. Library, 2004 (Boreas, 28), p. 9-14.

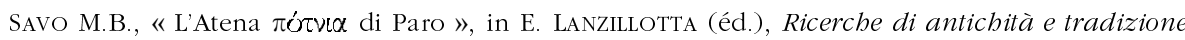
classica, Tivoli (Roma), Ed. Tored, 2004 (Richerche di filologia, letteratura e storia, 3), p. 173203.

SCUlLION Scott, "Tragedy and religion: the problem of origins », in J. GREGORY (éd.), $A$ Companion to Greek Tragedy, Oxford, Blackwell, 2005, p. 23-37.

Sommerstein A.H., " Tragedy and myth », in R. Bushnell (éd.), A Companion to Tragedy, Oxford, Blackwell, 2005, p. 163-180.

STRubBe J.H.M., " Cultic honours for benefactors in the cities of Asia Minor », in L. DE LIGT, E.A. HEMELRIJK, W. SingOR (éds), Roman rule and civic life: local and regional perspectives. Proceedings of the fourth workshop on intern. network 'Impact of empire' (Roman empire, c. 200 B.C. - A.D. 476). Leiden, June 25-28, 2003, Amsterdam, Gieben, 2004, p. 315-330.

TÉBAR MEgías Estíbaliz, « Mujeres guerreras en la mitología griega », in C. ALfARO GINER, E. TÉBAR MEGÍAs (éds), PROTAI GYNAIKES. Mujeres próximas al poder en la antigüedad, Valencia, 2005, p. $51-70$. 
VAN DER EIJK P.J., « Divination, prognosis and prophylaxis: the Hippocratic work 'On dreams' (De victu 4) and its Near Eastern background », in H.F.J. HoRstMANSHOFF, M. STOL (éds), Magic and rationality in ancient Near Eastern and Graeco-Roman medicine, Leiden, Brill, 2004 (Studies in ancient medicine, 27), p. 187-218.

ZEIMBEKI M., "The organisation of votive production and distribution in the peak sanctuaries of state society Crete: a perspective offered by the Juktas clay animal figures ", in G. CADOGAN, E. Hatzaki, A. Vasilakis (éds), Knossos. Palace, city, state. Proceedings of the conference in Herakleion organized by the British school at Athens and the 23th Ephoreia of prehistoric and classical antiquities of Herakleion, in November 2002, for the centenary of Sir Arthur Evans' excavations at Knossos, London, The British School at Athens, 2004, p. 351-361.

\section{Ouvrages reçus à la rédaction*}

BitTON-AshKelony Brouria, Encountering the Sacred. The Debate on Christian Pilgrimage in Late Antiquity, Los Angeles/London, University of California Press, 2005. 1 vol. $16 \times 23,5 \mathrm{~cm}$, $\mathrm{xv}+250$ p. ISBN : 0-520-24191-6.

BITTRICH Ursula, Aphrodite und Eros in der antiken Tragödie. Mit Ausblicken auf motivgeschichtlich verwandte Dichtungen, Berlin/New York, Walter de Gruyter, 2005. 1 vol. $16 \times 23 \mathrm{~cm}$, VIII+218 p. (Untersuchungen zur antiken Literatur und Geschichte, 75). ISBN : 3-11-0188555-5.

BODIOU Lydie, FrÈre Dominique, MEHL Véronique (éds), avec la collaboration d'Alexandre Tourraix, L'expression des corps. Gestes, attitudes, regards dans l'iconographie antique, Presses Universitaires de Rennes, 2006. 1 vol. $15,5 \times 24 \mathrm{~cm}, 385$ p. (Coll. Histoire. Cabiers d'histoire du corps antique, 2). ISBN : 2-7535-0204-8.

Borgeaud Philippe, Volokhine Youri (éds), Les objets de la mémoire. Pour une approche comparatiste des reliques et de leur culte, Bern et al., Peter Lang, 2005. 1 vol. $15 \times 22,5 \mathrm{~cm}, 357$ p. (Studia Religiosa Helvetica, 2004/05). ISBN : 3-03910-592-2.

Burger Maya, CAlame Claude (éds), Comparer les comparatismes. Perspectives sur l'bistoire et les sciences des religions, Paris/Milano, Edidit/Archè, 2006. 1 vol. $15,5 \times 22,5$ cm, 238 p. (Coll. Histoire de l'Histoire des religions, 2). ISBN : 2-912770-06-8.

Busine Aude, Paroles d'Apollon. Pratiques et traditions oraculaires dans l'Antiquité tardive (II'- VI siècles), Leiden, Brill, 2005. 1 vol. $16 \times 24,5 \mathrm{~cm}, 516$ p. (Religions in the Graeco-Roman World, 156). ISBN : 90-04-14662-8.

Calame Claude, Masques d'autorité. Fiction et pragmatique dans la poétique grecque antique, Paris, Les Belles Lettres, 2005. 1 vol. $15 \times 21$ cm, 335 p. (L'Âne d'or). ISBN : 2-251-42027-4.

CALAmE Claude, Pratiques poétiques de la mémoire. Représentations de l'espace-temps en Grèce ancienne, Paris, La Découverte, 2006. 1 vol. $13,5 \times 22 \mathrm{~cm}, 322$ p. (Textes à l'appui. Série Histoire classique). ISBN : 2-7071-4798-2.

CAMASSA Giorgio, La Sibilla giudaica di Alessandria. Ricerche di storia delle religioni, Firenze, Le Monnier, 2005. 1 vol. $17 \times 24$ cm, vI+237 p. (Studi Udinesi sul Mondo Antico, 3). ISBN : 88-0086113-X.

Currie Bruno, Pindar and the Cult of Heroes, Oxford, Oxford University Press, 2005. 1 vol. $14 \times$ $22 \mathrm{~cm}, \mathrm{XIV}+487$ p. (Oxford Classical Monographs). ISBN : 0-19-927724-9.

Des Bouvrie Synnøve (éd.), Myth and Symbol II. Symbolic phenomena in ancient Greek culture. Papers from the second and third international symposia on symbolism at the Norwegian Institute at Athens, September 21-24, 2000 and September 19-22, 2002, Bergen, 2004. 1 vol. $17,5 \times 24$ cm, 390 p. (Papers from the Norwegian Institute at Athens, 7). ISBN : 82-91626-22-7.

* Nous mentionnons dans cette rubrique tous les ouvrages reçus, en nous réservant le droit de ne pas en produire de compte rendu si le sujet n'entre guère dans la thématique de Kernos. Quant aux revues que nous recevons, leurs articles qui concernent la religion grecque, et eux seuls, sont repris dans la Revue des Revues. 